\title{
Abnormal Return Differences Before And After Amnesty Tax Policy 2016 - 2017 Period II And III (Event Study at Company divided in LQ45 Index)
}

\author{
Hadi Cahyono" Hafiz fitradiansyah ${ }^{2}$ \\ ${ }^{1,2)}$ Universitas Internasional Semen Indonesia \\ hadi.cahyono@uisi.ac.id, hafizfitradiansyah@gmail.com
}

\begin{abstract}
Purpose : The result of this research are expected to provide information to the investors to face the similar event so that investors can make decisions to taking profit in the future.

Design/methodology/approach : The model of this event study research is using 45 issuers of LQ45 indexes member during test period for 10 days before and after the event. The statistic test which used in this research is paired sample-test towards CAAR and counting t-test towards AAR..

Findings The result of CAAR is showed that CAAR abnormal return significantly merely happen in research period III. While, for t-test towards AAR showed that abnormal return happened in period II and III tax amnesty execution

Research limitations/implications : The object of this research is company which recorded as a member in LQ45 indexes.

Practical implications : The result of CAAR is showed that CAAR abnormal return significantly merely happen in research period III. While, for t-test towards AAR showed that abnormal return happened in period II and III tax amnesty execution, with details in period II abnormal return merely happen in $t-1$ with negative value and period III abnormal return happen in $t-9, t-8, t-4, t-3, t+1$ and $\mathrm{t}+9$.

Originality/value : expected to provide information to the investors to face the similar event so that investors can make decisions to taking profit in the future Paper type : Research paper
\end{abstract}

Keyword : tax amnesty, event study, average abnormal return (AAR), cumulative average abnormal return $(C A A R)$

Abnormal Return Differences Before And After Amnesty Tax Policy 2016 - 2017 Period II And III (Event Study at Company divided in LQ45 Index)

Hadi Cahyono, Hafiz fitradiansyah 


\section{INTRODUCTION}

Capital market is one of economy booster instruments of a country. As the economy booster instrument, capital market, of course, is not free from many kinds of influences both internally and externally or economically and noneconomically. Such as: political factor, social factor and so on. By those kinds of influential factors, hence capital market, especially for the company, will be more sensitive and selective in receiving circulated information. Market information absorption will be very influencing in psychological aspect for the investor and also for capital market movement. Some micro economy influences, such as: financial statement, devident sharing, business development until positive and negative news will influence the investors in choosing the emitent as the infestation object. Moreover, macro economy influences, such as: currency rate changes amongst the country, regulation changes by the government of the country, many kinds of economical data, and conductivity of infestation climate in a country, can give big impact for capital market commerce especially in commerce volume and also price fluctuation for the emitent and indexes in a country.

Indonesia has become one of infestation targets for global investors. It is reflected in Global Investment Trends Monitor report released by United Nations that put Indonesia in $9^{\text {th }}$ rank as the MNEs' Top Prospective Host Economies for 2016-2018. It is also supported by the return IHSG record-keeping period 2016 as much as $15.32 \%$ that outpoint of obligation (10.36\%) and forex (7-9\%). The high return is not free from the emitent and government efforts to collect fund from the society to get into the capital market. By that high return, IHSG can become a reflection of convenient investment climate of a country for the investor. It is proven in the early 2017 , domestic investor finally can dominate Indonesian capital market as high as $51.6 \%$ compared with foreign investor as high as $49.4 \%$. Based on the data released by PT. Kustodian Sentral Efek 
Indonesia (KSEI), noted that per January $13^{\text {th }}, 2017$, the number of registered Single Investor Identification (SID) is as many as 903.304 people or increasing $106.58 \%$ year to date, where in January 2016 , the recorded investors are only 444.319 persons (beritasatu.com, 2017). Supported by many positive sentiments of company's performance that try to be improved by the emitents and also many policy packages of the government, one of them is tax amnesty.

Beside capital market, the main element in manipulating economy wheel of a country is the State General Revenue and Expenditures Budgets (APBN). It becomes a capital for the country in fulfilling the expenses of government programs implementation and also in making society prosperous through many kinds of needs such as: basic needs fulfillment, facilities of subsidy in many sectors and also infrastructure development. The needs of management system in State General Revenue and Expenditures Budgets (APBN) is expected to be able to gain economy growth according to the defined target, to gain economical stability, management of state general revenue and determination of way of development policy fundamentally. Many kinds of fund resources from State General Revenue and Expenditures Budgets (APBN), one of them is tax amnesty. Tax becomes very important because it is the main resourse of state income. However, the less awareness of taxpayers to meet their demands has the impact on the lost of optimum tax potency which can be gained. Although, BPS data shows that until 2013, the number of Indonesian worker is 93.72 million people, but this number is inversely proportional to taxpayers data until 2015 , which is only 30.044 .103 taxpayers or $29.4 \%$ with the details are: 2.472.632 agency taxpayers, 5.329.385 non-worker-private taxpayers, and 22.332.086 worker-private taxpayers.

The more and more expenses used to support Infrastructure according to NAWACITA program of president of Joko Widodo; hence it needs many kinds of stimulus to get society interest to become more aware to meet their demand 
to pay their tax to the country that one of them is through tax amnesty that stated in Law number 11 years 2016 about Tax Amnesty legalized on July $1^{\text {st }}$, 2016 and start to apply on July $18^{\text {th }}, 2016$ and devided into some period of programs.

Investment fund resources meant here is come from assets repatriachy that is a process of returning income accumulation in the form of assets or property outside Indonesia back into Indonesia area (Law No. 11 years 2016). While, the repatriachy fund has the obligation to be invested according to section 12 subsections 1 until 3 Law of Tax Amnesty which explains about the clause of period of fund transfer to be invested and some instruments which can be used as investment objects, one of them is stock in Indonesia capital market.

The other urgency of the assets repatriachy of tax amnesty 2016 is the magnitude of fund potency that less absorbed optimally. There are some assumptions supporting the argument based on the citation from presentation slide released by Finance Directorate of Technology Institute of Bandung about the introduction of Tax Amnesty. They are:

1. McKinsey Company estimates that there are about US $\$ 250$ milliard Indonesian's assets in overseas

2. Credit Suisse Global Wealth Report and Allianz Global Wealth Report shows that Indonesian's assets in overseas is about Rp 11.125 Billion

3. Indonesia Bank estimates the number of Indonesian illicit funds in oversears is as much as Rp 3.147 billion (Sources: Kar and Spanjers (2015), Tax Justice Network (2010) and Global Financial Integrity (2015))

4. Based on the primary data, Ministry of Finance estimates the total of Indonesian assets in overseas is as much as Rp 11.000 billion for minimum.

The hardly application of this tax amnesty 2016 policy gives good result. It is proven by the achievement cited in the program of Business Liputan 6 is as follow: 
1. Total assets reported by taxpayers reach Rp. 4.855 billion, which consists of: domestic assets declaration Rp. 3.676 billion and overseas assets declaration 1.031 billion, while repatriachial assets are as much as Rp. 147 billion. Compensation fund becoming state's income reaches Rp. 135 billion that consists of: compensation fund Rp. 114 billion, beginning voucher payment Rp. 1.75 billion and back payment is as much as Rp. 18.6 billion.

2. The recorded member of tax amnesty is 956 thousand taxpayers.

The existence of Index fluctuation around the beginning period of tax amnesty program in each period, at once also prove that LQ45 index will move linearly with IHSG. While the respond to market price, from technical analytical point of view, around the $\mathrm{H}$-day of each early period it can be found taking-profit action. This matter bases whether the spreaded information about tax amnesty influencing market sentiment that making price fluctuate and automatically will give an opportunity for the investor to get abnormal return. Beside that, the achievement of IHSG improvement that reaches over Break New High compared with 2015 is more reflecting positive response of marketing agents.

From the description above, it can be assumed that the tax amnesty policy can raise a sentiment for the investor to invest in Indonesia. Riskhy and Nadia (2014) in their journal about The Pre- and Post-Reaction of Fuel Markup On The Listing Company in Indonesia Bursary Effect (BEl) shows that fuel markup can give positive abnormal return and Trading Volume Activity, both before and after the policy being applied. However the reversal result is concluded by the research of Ervina and Dwi (2014) in their journal about Indonesia Capital Market's Reaction to The Announcement of Fuel Markup on June $22^{\text {nd }}, 2013$. It is shown that there is no any significant difference in Abnormal Return between pre- and post-event, but Trading Volume Activity still shows it.

It is very different with the research done by Cynthia (2015) in her thesis

Abnormal Return Differences Before And After Amnesty Tax Policy 2016 - 2017 Period II And III (Event Study at Company divided in LQ45 Index)

Hadi Cahyono, Hafiz fitradiansyah 
about The Difference of Abnormal Return and Trading Volume Activity pre- and post-The Announcement of Regulation Number 1 year 2014, shows that government policy to launch a new regulation related with the implementation of minerals and coals mining business has significant difference on Abnormal Return Average and Trading Volume Activity. While on Rahayu's research (2016), her thesis about Analysis of Capital Market Reaction to The Policy of Tax Amnesty (Case Study on Syariah Stocks recorded in Jll period JuneNovember 2016) shows that tax amnesty gives impact on the differentiation of Abnormal Return and Trading Volume Activity pre-and post-event.

Research about tax amnesty was also done by Wendi, Nur \& Afifudin (2016) in a journal about The Investor's Reaction to The Announcement of Tax Amnesty Policy on July $1^{\text {st }}, 2016$ (Event Study on LQ45 Enterprise registered in BEl) concluded that there is significant abnormal return in $t-6$ that is on June $23^{\text {rd }}, 2016$ for exactly. Yet, after the analysis using Paired Sample t-test, the obtained result shows that there is no any difference on abnormal return both before and after the announcement of tax amnesty policy in the first period that is on July $1^{\text {st }}, 2016$.

From some facts above, it can be concluded that this topic will see how the investors will react to the implementation of tax amnesty, because of the existence of re-investment in Indonesia through compensation and repatriate fund which is paid by taxpayers. It raises the optimism amongs the investors in relation with the economical improvement in Indonesia and the capital market become more liquid, so that it motivates the investors to troop investing their capital, either to get short-term or long-term profits, that is reflected to the expected Abnormal Return as the reaction of investors on making transaction in capital market. So that, the title of this research is "The Difference of Abnormal Return pre- and post-tax amnesty policy 2016-2017 Period II and III (Event Study on The Companies Recorded in LQ45 Indexes)"

Abnormal Return Differences Before And After Amnesty Tax Policy 2016 - 2017 Period II And III (Event Study at Company divided in LQ45 Index)

Hadi Cahyono, Hafiz fitradiansyah 


\section{MATERIAL AND METHOD}

The applied research method here is event study by using an approach through abnormal return. Event study is often used by the researcher in accounting sector to track the reaction of market to an event happened in a company, such as: the policy of decision making to the corporation, and also out of the company, such as: global issue and government policy (Rianti, 2007). Through those events, it will be observed whether the stockholder will get abnormal return from the capital market movement influenced by a certain event. This research will try to find out whether the tax amnesty policy period II and III has impact from abnormal return side that reflected in capital market.

Population of this research is 45 companies recorded in LQ45 stock indexes. The main reason to choose LQ45 as the research object is because those companies included in LQ45 group are the companies with good performance both among the sub-indexes under the other IHSG in the matter of liquidity and also in commercial volume. Besides, LQ45 is an index composed from many kinds of companies that run in IHSG sectoral with good performance in fundamental reports. So, it is expected by choosing those companies, it will give added significance for the investors in order to get positive results from their investment in stock exchange.

Resource and kinds of data used in this research is secondary data in the form of documentation of data recapitulation consisting of market closing price and emitent, and various news about tax amnesty period I (July, $1^{\text {st }}-$ September, $31^{\text {st }} 2016$ ), period II (October, $1^{\text {st }}$ - December, $31^{\text {st }} 2016$ ), and period III (January, $1^{\text {st }}-$ March, $31^{\text {st }} 2017$ ) which are processed from many kinds of resources, such as: website and utilizes marketing system of Online Autonomous Security Trading. While for supporting the accuracy and the credibility of Information offered, hence it is also taken some seconder 
Volume 1 Number 12017

This work is licensed under a Creative Commons Attribution-

ShareAlike 4.0 International License.

informations obtained from Journals, books, and some related articles.

Sampling period is divided into two periods, they are: pre-event is during 10 days and post-event is also for 10 days. This research is using method of market-adjusted model in calculating event study, so the estimation period is not used. Whereas, the time-series graphic can be seen in picture 2.1 and picture 2.2
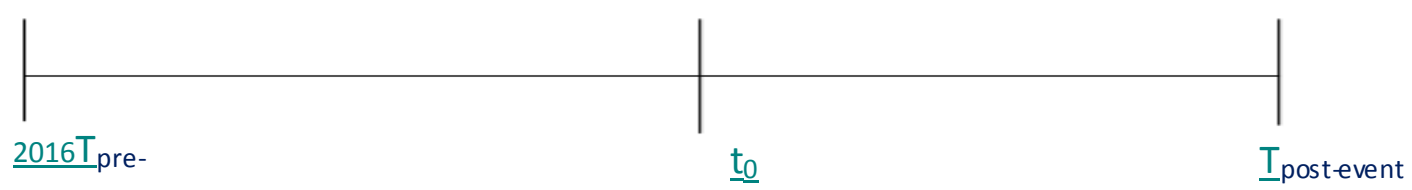

event

October

October

Picture 2.1. Sampling Periode of Tax Amnesty Period II

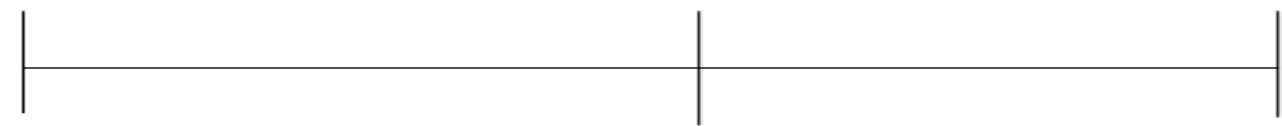

Tpre-event

December $15^{\text {th }}$, $\underline{t}_{0}$

Januari $1^{\text {st }}$

$\underline{2017}$
Ipostevent January $17^{\text {th }}, \underline{2017}$

Picture 2. 1 Sampling Period of tax amnesty period III

This research uses quantitative analysis to measure the level of abnormal return and then the data processed econometrically will be interpreted.

Statistical data in the form of close price from IHSG and emitent of the member of LQ45 index will be processed by using Microsoft Excel 2016 and SPSS 20 softwares. Data analysis technique uses Kolmorgov-Smirnov normality test, paired sample t-test and also the comparison between t-count and t-table. While, the application of those three methods are explained as follow: 
1. Kolmogorov-Smirnov Normality test

Previously, the data that will be processed must be checked whether it has been distributed normally through normality test. Normality test is a testing method in statistic to know data distribution in the variable used in this research (Agung, 2015). This normality test can be seen through Kolmogorov-Smirnov method under the assumption that data will be stated as distributed normally if the significance level of the processed data is higher than 0.05 . While, if the significance level of the processed data is lower than 0.05 , it will be assumed that the data is not distributed normally.

2. Difference Test of Paired sample t-test

When the processed data is assumed to be distributed normally through Kolmogorov-Smirnov Normality test, then the data will be tested by using differential test. It has some testing method, such as: independent sample ttest, paired sample t-test and one sample t-test. In this research, the testing method used is paired sample t-test in order to determine whether there is any average difference of the two free samples (the same sample, but have two difference data) (Agung, 2015).

3. T-count difference test.

\section{RESULT AND DISCUSSION}

Indonesia Stock Bursary (BEI) is the caretaker institution and the organizer of capital market in Indonesia. Organizational-structurally, BEI, clearance institution, and Guarantee of Indonesia stock Clearance Pledgin (KPEI), and Institution of Saving and Settlement of Indonesia Stock Central-Custodian (KSEI) are capital market institutions under Finance Service Authority (OJK) as the institution that manage and supervise integrated in whole activities included in finance service sector.

At this moment, Indonesia stock bursary (BEI) has 545 members of 
company emitent consists of 10 industrial sectors, they are: Agriculture, Mining, Basic Industry and Chemical, Miscellaneous Industry, Consumer Goods Industry, Property, Infrastructure, Finance and Trading. To make the investor easier in choosing the emitent, BEI give solution by agglomerate the emitents in the smaller categories or indexes. The indexes are made based on the classification or the rules that must be fulfilled by the emitent in order to be able to join in it. The indexes are LQ45, KOMPAS100, JII, PEFINDO25, SRIKEHATI, ISSI, INFOBANK15, IDX30, etc. From those indexes, LQ45 becomes one of investor's favourite indexes because it consists of many companies with good performance, such as: PT. Semen Indonesia (Persero) Tbk., PT. Telkom Indonesia Tbk., PT. Adhi Karya (Persero) Tbk. Etc. Cited from sahamgain.com, LQ45 indexes can be used as the reflection of IHSG. It is because of the correlation of LQ45 Indexes and IHSG reaches $99.99 \%$.

\section{The Testing Result of Hypothesis 1}

To track the market response on the success gained by tax amnesty period II (October - December 2016), hence the first hypothesis states that there is significant abnormal return difference on LQ45 indexes pre- and postapplication event of tax amnesty policy period II (October - December 2016). Below is the graphic and table of CAAR movement during research period.

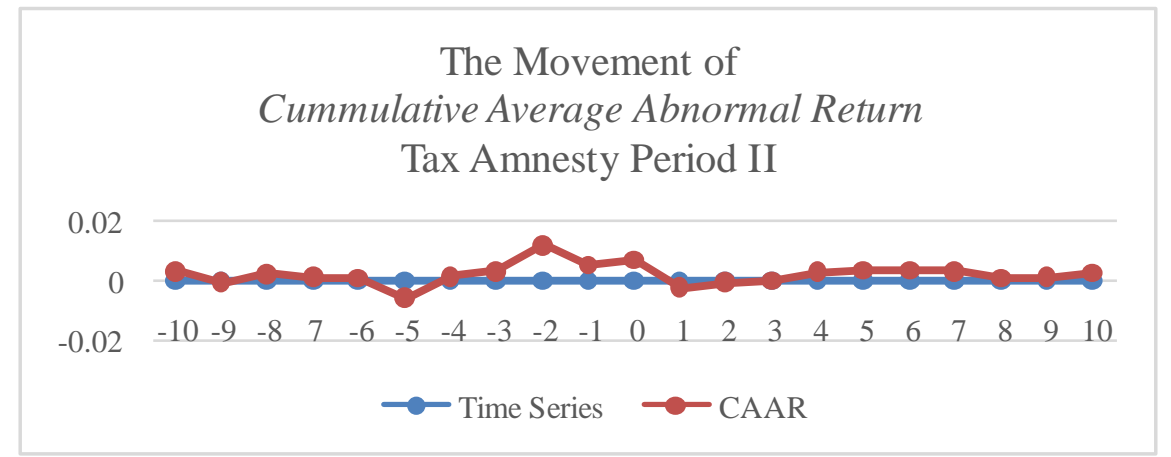

Graphic 3.1 Cummulative Abnormal Return of Tax Amnesty period II

Abnormal Return Differences Before And After Amnesty Tax Policy 2016 - 2017 Period II And III (Event Study at Company divided in LQ45 Index)

Hadi Cahyono, Hafiz fitradiansyah 
Volume 1 Number 12017

This work is licensed under a Creative Commons Attribution-

ShareAlike 4.0 International License.

Table 3.1

Average Abnormal Return and Cumulative Average Abnomal Return pre- and post-event of tax amnesty period II

\begin{tabular}{|c|c|c|c|c|c|}
\hline $\begin{array}{l}\text { Day } \\
\text { of-t }\end{array}$ & $\begin{array}{l}\text { AAR } \\
\text { Pre- } \\
\text { event }\end{array}$ & $\begin{array}{c}\text { CAAR } \\
\text { pre- } \\
\text { event }\end{array}$ & $\begin{array}{l}\text { Day } \\
\text { of -t }\end{array}$ & $\begin{array}{l}\text { AAR } \\
\text { post- } \\
\text { event }\end{array}$ & $\begin{array}{l}\text { CAAR } \\
\text { post- } \\
\text { event }\end{array}$ \\
\hline-10 & $\begin{array}{c}0.003 \\
05\end{array}$ & $\begin{array}{c}0.003 \\
05\end{array}$ & 1 & $\begin{array}{c}- \\
0.002 \\
27\end{array}$ & $\begin{array}{c}- \\
0.002 \\
27\end{array}$ \\
\hline-9 & $\begin{array}{c}- \\
0.003 \\
51\end{array}$ & $\begin{array}{c}- \\
0.000 \\
46\end{array}$ & 2 & $\begin{array}{c}0.001 \\
53\end{array}$ & $\begin{array}{c}- \\
0.000 \\
75\end{array}$ \\
\hline-8 & $\begin{array}{c}0.002 \\
79\end{array}$ & $\begin{array}{c}0.002 \\
33\end{array}$ & 3 & $\begin{array}{c}0.000 \\
57\end{array}$ & $\begin{array}{c}- \\
0.000 \\
18\end{array}$ \\
\hline-7 & $\begin{array}{c}- \\
0.001 \\
28\end{array}$ & $\begin{array}{c}0.001 \\
05\end{array}$ & 4 & $\begin{array}{c}0.003 \\
05\end{array}$ & $\begin{array}{c}0.002 \\
87\end{array}$ \\
\hline-6 & $\begin{array}{c}- \\
0.000 \\
08\end{array}$ & $\begin{array}{c}0.000 \\
97\end{array}$ & 5 & $\begin{array}{c}0.000 \\
71\end{array}$ & $\begin{array}{c}0.003 \\
58\end{array}$ \\
\hline-5 & $\begin{array}{c}- \\
0.006 \\
95\end{array}$ & $\begin{array}{c}- \\
0.005 \\
98\end{array}$ & 6 & $\begin{array}{c}- \\
0.000 \\
20\end{array}$ & $\begin{array}{c}0.003 \\
38\end{array}$ \\
\hline-4 & $\begin{array}{c}0.007 \\
37\end{array}$ & $\begin{array}{c}0.001 \\
39\end{array}$ & 7 & $\begin{array}{c}- \\
0.000\end{array}$ & $\begin{array}{c}0.003 \\
10\end{array}$ \\
\hline
\end{tabular}

Abnormal Return Differences Before And After Amnesty Tax Policy 2016 - 2017 Period II And III (Event Study at Company divided in LQ45 Index)

Hadi Cahyono, Hafiz fitradiansyah 
Volume 1 Number 12017

This work is licensed under a Creative Commons Attribution-

ShareAlike 4.0 International License.

\begin{tabular}{|ccc|ccc|}
\hline & & & \multicolumn{3}{|c|}{28} \\
\hline-3 & $\begin{array}{c}0.001 \\
66\end{array}$ & $\begin{array}{c}0.003 \\
04\end{array}$ & 8 & $\begin{array}{c}0.002 \\
19\end{array}$ & $\begin{array}{c}0.000 \\
91\end{array}$ \\
\hline-2 & $\begin{array}{c}0.009 \\
02\end{array}$ & $\begin{array}{c}0.012 \\
06\end{array}$ & 9 & $\begin{array}{c}0.000 \\
12\end{array}$ & $\begin{array}{c}0.001 \\
03\end{array}$ \\
\hline-1 & $\begin{array}{c}0.006 \\
95\end{array}$ & $\begin{array}{c}0.005 \\
11\end{array}$ & 10 & $\begin{array}{c}0.001 \\
61\end{array}$ & 0.002 \\
& & & & & 64 \\
\hline
\end{tabular}

The movement of CAAR value pre- and post-event shows the incisive fluctuation, where the market is reacted for some days before the tax amnesty period II is implemented. For exactly, it is started on t-5 where a very significant lowering happens with abnormal return accumulation value reaches -0.00598 or $0.598 \%$. Yet, rebound is happened continuously on the next day until t-2 of preevent with the highest abnormal return accumulation value reaches 0.01206 atau $1.206 \%$. However, on the next day, the $1^{\text {st }}$ day of pre-event, for exactly, it is happened the ongoing lowering or bearish of CAAR value until the $1^{\text {st }}$ day of post-event that reaches -0.00227 or $0.227 \%$. After the bearish moment, market starts to increase again step by step on the day after tax amnesty period II being implemented. 
Volume 1 Number 12017

This work is licensed under a Creative Commons Attribution-

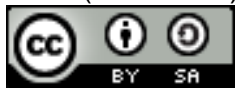

ShareAlike 4.0 International License.

The result of statistical testing on tax amnesty policy period II can be seen on the following table.

Table 3.2

The result of t-test of Cummulative Average Abnormal Return of tax amnesty period

Paired Samples Test

\begin{tabular}{|c|c|c|c|c|c|c|c|c|}
\hline & \multicolumn{5}{|c|}{ Paired Differences } & \multirow[t]{3}{*}{$\mathrm{T}$} & \multirow[t]{3}{*}{$d f$} & \multirow{3}{*}{$\begin{array}{l}\text { Sig. } \\
\text { taile }\end{array}$} \\
\hline & \multirow[t]{2}{*}{ Mean } & \multirow[t]{2}{*}{$\begin{array}{c}\text { Std. } \\
\text { Deviatio } \\
\mathrm{n}\end{array}$} & \multirow[t]{2}{*}{$\begin{array}{l}\text { Std. } \\
\text { Error } \\
\text { Mean }\end{array}$} & \multicolumn{2}{|c|}{$\begin{array}{c}95 \% \text { Confidence } \\
\text { Interval of the } \\
\text { Difference }\end{array}$} & & & \\
\hline & & & & Lower & Upper & & & \\
\hline $\begin{array}{l}\text { Pai Sebelum } \\
\text { r1 - Setelah }\end{array}$ & $\begin{array}{r}, 0006 \\
1530\end{array}$ & $\begin{array}{r}, 005351 \\
30\end{array}$ & $\begin{array}{r}, 00169 \\
223\end{array}$ & $\begin{array}{r}, 003212 \\
79\end{array}$ & $\begin{array}{r}, 004443 \\
39\end{array}$ & ,364 & 9 &, $\bar{t}$ \\
\hline
\end{tabular}

Based on the statistical test result on table 3.2, it can be seen that there is a difference on mean value of CAAR between pre- and post-event that is 0.00061530 , shows that CAAR value before the implementation of tax amnesty period II is higher than post-event. It means that the market is welcoming the implementation of tax amnesty period II.

It can be seen that t-count of SPSS application process is 0.364 and has probability as much as 0.725 . By seeing that probability value is $>0.05$, hence $\mathrm{H}_{0}$ is failed to be rejected and raises an assumption that there is no any significance accumulation difference on abnormal return both pre- and postevent of tax amnesty 2016-2017 period II. 
Volume 1 Number 12017

This work is licensed under a Creative Commons Attribution-

\section{Testing Result of Hypothesis 2}

To check market response to the achievement of tax amnesty period III, hence the second hypothesis states that there is a significant difference on abnormal return on LQ45 indexes both pre- and post-event of tax amnesty policy period III (January - March 2017) being applied. Below is graphics and table of CAAR movement during research period:

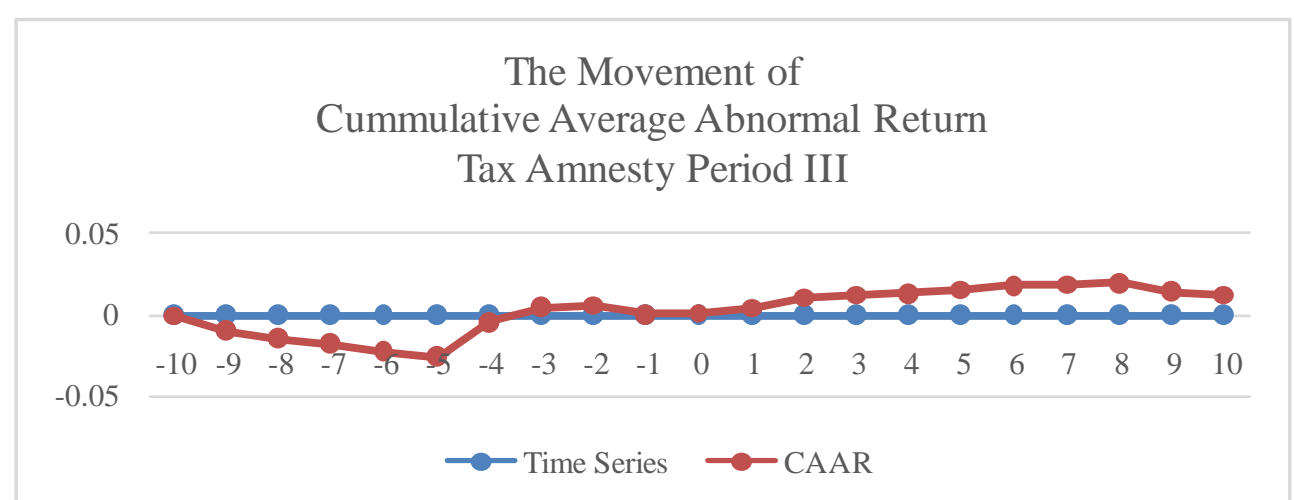

Graphic 3.2. Cummulative Abnormal Return of Tax Amnesty Period III

Table 3.3

Average Abnormal Return and Cumulative Average Abnomal Return pre- and post-event of tax amnesty period III

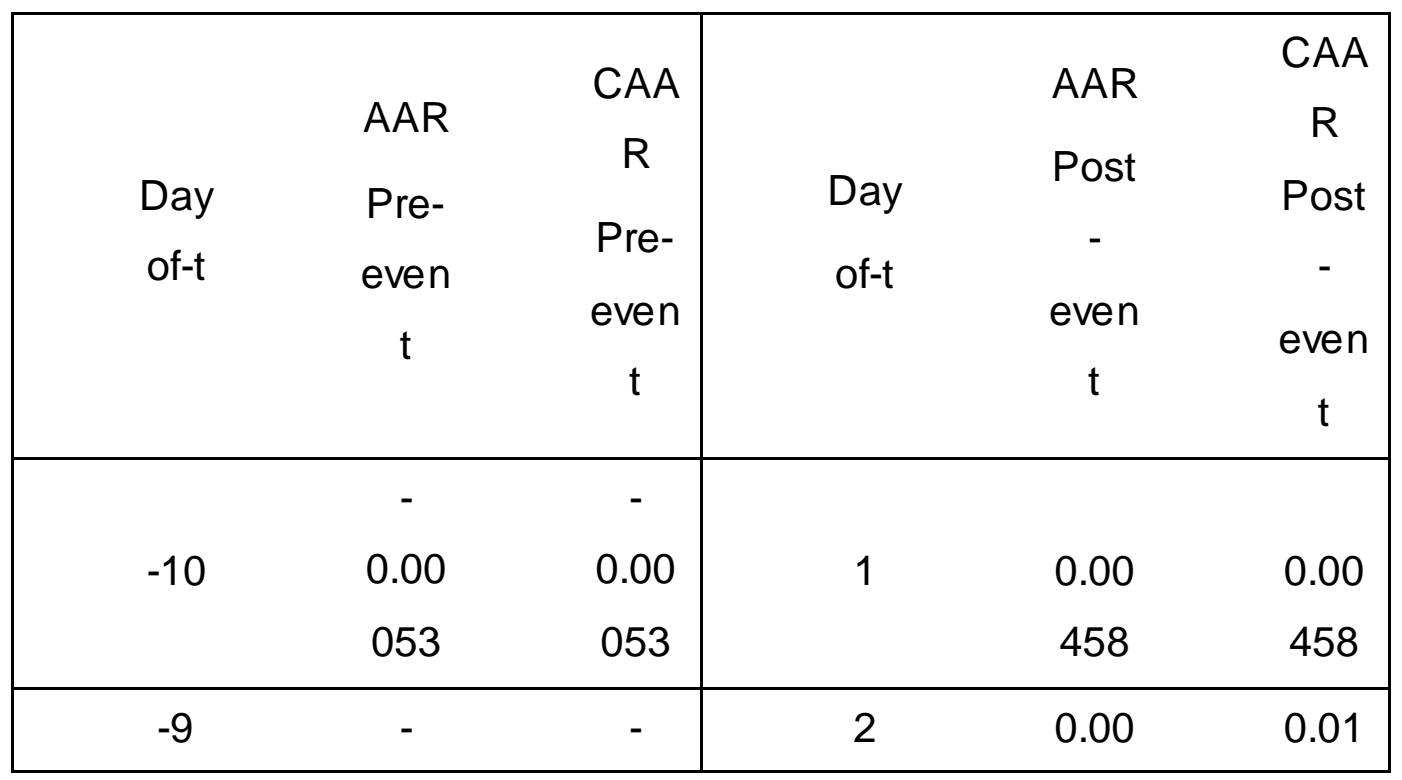

Abnormal Return Differences Before And After Amnesty Tax Policy 2016 - 2017 Period II And III (Event Study at Company divided in LQ45 Index)

Hadi Cahyono, Hafiz fitradiansyah 
Volume 1 Number 12017

This work is licensed under a Creative Commons Attribution-

ShareAlike 4.0 International License.

\begin{tabular}{|c|c|c|c|c|c|}
\hline & 0.00 & 0.00 & & 614 & 072 \\
\hline & 915 & 967 & & & \\
\hline & - & - & & & \\
\hline-8 & 0.00 & 0.01 & 3 & 0.00 & 0.01 \\
\hline & 499 & 466 & & 193 & 265 \\
\hline-7 & 0.00 & 0.01 & 4 & 0.00 & 0.01 \\
\hline & 294 & 760 & & 042 & 307 \\
\hline & - & - & & & \\
\hline-6 & 0.00 & 0.02 & 5 & 0.00 & 0.01 \\
\hline & 492 & 253 & & 242 & 549 \\
\hline-5 & 0.00 & 0.02 & 6 & 0.00 & 0.01 \\
\hline & 324 & 577 & & 306 & 855 \\
\hline-4 & 0.02 & 0.00 & 7 & 0.00 & 0.01 \\
\hline & 142 & 435 & & 040 & 895 \\
\hline 3 & 0.00 & 0.00 & 8 & 0.00 & 0.01 \\
\hline-0 & 919 & 484 & 8 & 100 & 994 \\
\hline & & & & - & \\
\hline-2 & 0.00 & 0.00 & 9 & 0.00 & 0.01 \\
\hline & 121 & 605 & & 553 & 441 \\
\hline & - & - & & - & \\
\hline-1 & 0.00 & 0.00 & 10 & 0.00 & 0.01 \\
\hline & 053 & 053 & & 200 & 241 \\
\hline
\end{tabular}

Abnormal Return Differences Before And After Amnesty Tax Policy 2016 - 2017 Period II And III (Event Study at Company divided in LQ45 Index)

Hadi Cahyono, Hafiz fitradiansyah 
Volume 1 Number 12017

This work is licensed under a Creative Commons Attribution-

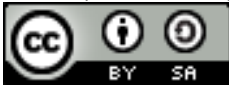

ShareAlike 4.0 International License.

From the table 3.3 above, it can be seen that the movement of CAAR value pre- and post-event has the tendency to move fluctuative to positive way. It is proven by CAAR value that continuously lowering at the beginning, start from $\mathrm{t}-10$ until $\mathrm{t}-5$ before the tax amnesty period III start to applied, until reaches -0.02577 or $2.577 \%$. Yet, on the next day, LQ45 index rebounds again to bullish high enough for 3 days and the positive trend is stopped on t-1 when tax amnesty period III is started. Although it is slow, but on the first day until hereafter it increases step by step on accumulation value of abnormal return until reaches the highest point on $\mathrm{t}-8$ that is 0.01994 or $1.994 \%$.

The statistical test result on the tax amnesty policy period III can be seen on the following table.

Table 3.4

The t-test result of Cummulative Average Abnormal Return of tax amnesty period III

Paired Samples Test

\begin{tabular}{|c|c|c|c|c|c|c|c|c|}
\hline & & Pair & ed Differe & nces & & $t$ & df & Sig. \\
\hline & Mean & $\begin{array}{l}\text { Std. } \\
\text { Deviati } \\
\text { on }\end{array}$ & $\begin{array}{l}\text { Std. } \\
\text { Error } \\
\text { Mean }\end{array}$ & $\begin{array}{r}95 \% \text { Co } \\
\text { Interva } \\
\text { Differ }\end{array}$ & $\begin{array}{l}\text { nfidence } \\
\text { I of the } \\
\text { ence }\end{array}$ & & & \\
\hline & & & & Lower & Upper & & & \\
\hline $\begin{array}{l}\text { Pai Pre- } \\
\text { r1 Post }\end{array}$ & $\begin{array}{r}, 02243 \\
000\end{array}$ & $\begin{array}{r}, 01284 \\
623\end{array}$ & $\begin{array}{r}, 004062 \\
34\end{array}$ & $\begin{array}{r}031619 \\
64\end{array}$ & $\begin{array}{r}013240 \\
36\end{array}$ & $\begin{array}{r}5,52 \\
1\end{array}$ & 9 & ו' \\
\hline
\end{tabular}


Based on the statistical test result on table 3.4 above, there is a difference on CAAR mean values between pre $=$ and post-event as much as -0.022430 . It means that CAAR value in post-event is higher than pre-event. So, it can be assumed that the investors give positive response to the result of tax amnesty period II.

It can be seen that t-count of SPSS application processing result is -5.521 and has the probability as much as 0,000 . While, Because of the probability value is $<0.05$ hence $\mathrm{H}_{0}$ is rejected and raises the assumption that there is significant accumulation difference of abnormal return on pre- and post-event of tax amnesty 2016-2017 implementation period III.

\section{Testing result of Hypothesis 3}

Market response is happened on the company registered in LQ45 indexes. Third hypothesis states that there is a day which has significant abnormal return on LQ45 index both pre-and post-event of tax amnesty policy periode II (October - December 2016) being applied. The table below draws the result of t-count test to Average Abnormal Return from all emitens registered in LQ45 period II.

Table 3.5

T-count test to Average Abnormal Return all emitent LQ45 in tax amnesty period II

\begin{tabular}{|cccc|cccc|}
\hline D & AA & & T & D & AA & & T \\
a & R & T- & - & a & R & T- & - \\
y & pr & cou & T & y & po & co & T \\
& e- & nt & a & & st- & un & a \\
o & ev & & b & o & ev & t & b \\
f & en & & I & f & en & & I
\end{tabular}

Abnormal Return Differences Before And After Amnesty Tax Policy 2016 - 2017 Period II And III (Event Study at Company divided in LQ45 Index)

Hadi Cahyono, Hafiz fitradiansyah 
Volume 1 Number 12017

This work is licensed under a Creative Commons Attribution-

ShareAlike 4.0 International License.

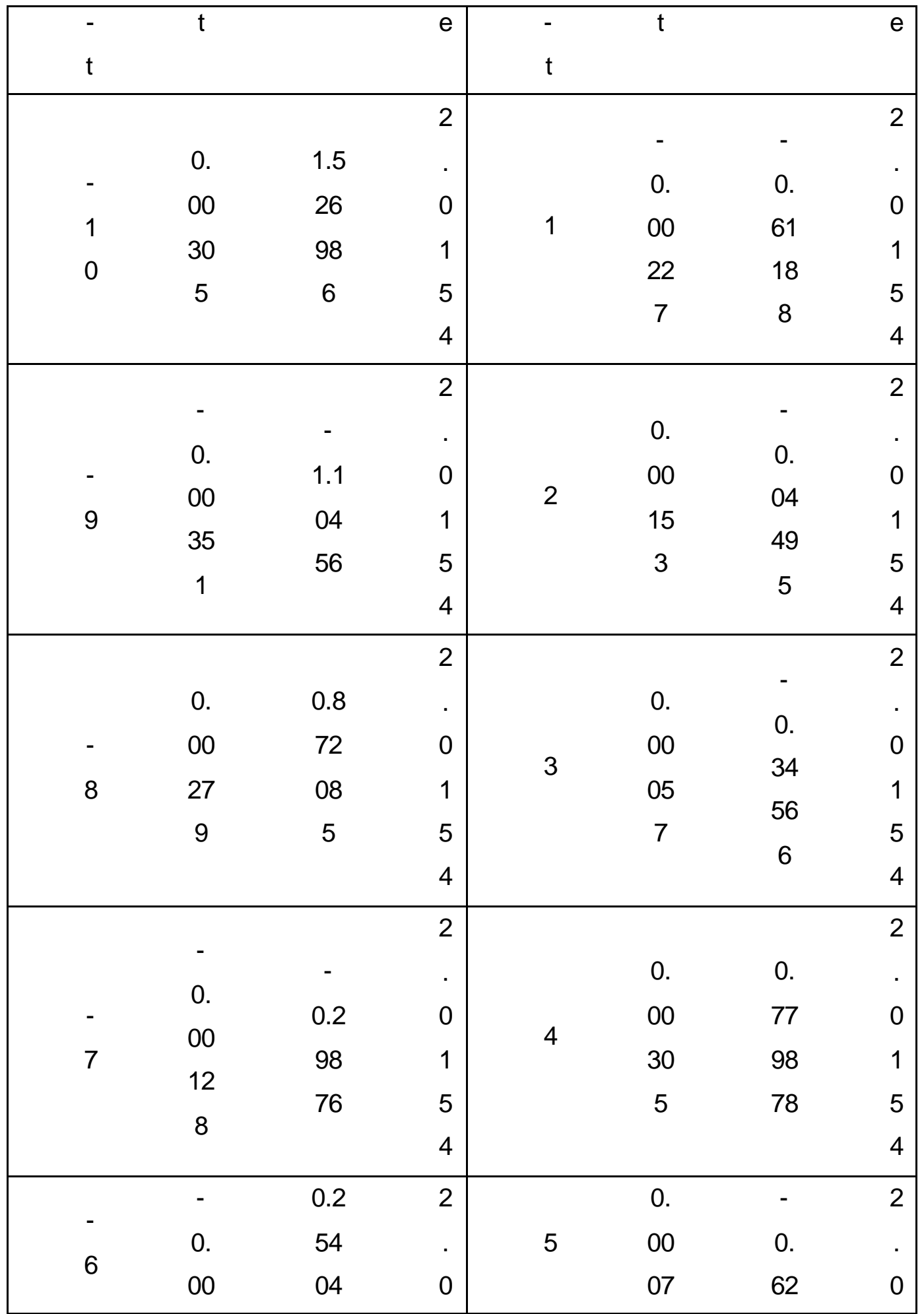

Abnormal Return Differences Before And After Amnesty Tax Policy 2016 - 2017 Period II And III (Event Study at Company divided in LQ45 Index)

Hadi Cahyono, Hafiz fitradiansyah 
Volume 1 Number 12017

This work is licensed under a Creative Commons Attribution-

(2) $(1)$

ShareAlike 4.0 International License.

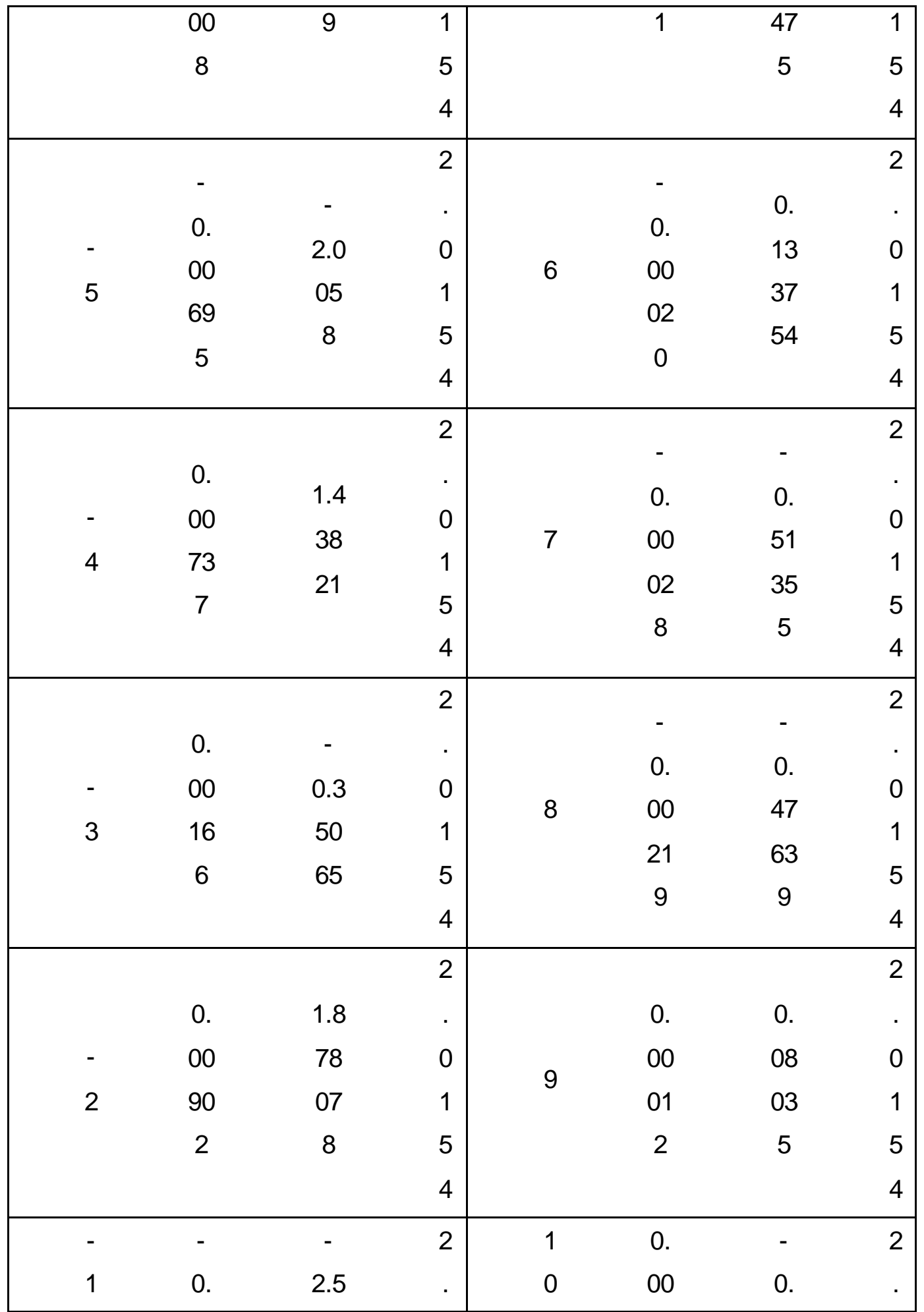

Abnormal Return Differences Before And After Amnesty Tax Policy 2016 - 2017 Period II And III (Event Study at Company divided in LQ45 Index)

Hadi Cahyono, Hafiz fitradiansyah 


\begin{tabular}{|ccc|cccc|}
\hline 00 & 18 & 0 & 16 & 39 & 0 \\
69 & 96 & 1 & 1 & 27 & 1 \\
5 & & 5 & & 8 & 5 \\
& & 4 & & & 4 \\
\hline
\end{tabular}

Table 3.5 above shows that on the $2^{\text {nd }}$ event, there is only one day where significant abnormal return happened that is $\mathrm{t}-1$ pre-event with significance value is as much as -2.51896 .

Besides, table 4.9 shows that there is positive value of average abnormal return (AAR) as many as 11 days and negative $A A R$ as many as 9 days. While for the highest $A A R$ is existed in the $2^{\text {nd }}$ day of pre-event that is 0.00902 or $0.902 \%$, while for the lowest AAR as much as -0.02958 or $-2.958 \%$ is existed on the $1^{\text {st }}$ and $5^{\text {th }}$ days of pre-event. While, the entire AAR t-count shows that there is significant $\mathrm{t}$-count or be outside the rejection area $\mathrm{H}_{0}$ so it can be concluded that there is significant abnormal return on $\mathrm{t}-1$ or the $1^{\text {st }}$ day of pre-event.

\section{Testing Result of Hypothesis 4}

When the fluctuative market response is happened on the companies registered in LQ45 indexes, hence the $4^{\text {th }}$ hypothesis testing states that there is a day with significant abnormal return on LQ45 indexes both pre- and postevent tax amnesty policy period III (January - March 2016) being applied. It can be seen on the following table.

Table 3.6

T-count test to the Average Abnormal Return of all emitent LQ45

Tax amnesty period III

\begin{tabular}{|cccc|ccccc|}
\hline $\mathrm{D}$ & $\mathrm{AA}$ & $\mathrm{T}-$ & $\mathrm{T}$ & $\mathrm{D}$ & $\mathrm{AA}$ & $\mathrm{T}-$ & $\mathrm{T}$ \\
$\mathrm{a}$ & $\mathrm{R}$ & $\mathrm{cou}$ & - & $\mathrm{a}$ & $\mathrm{R}$ & $\mathrm{coun}$ & - \\
$\mathrm{y}$ & $\mathrm{pr}$ & $\mathrm{nt}$ & $\mathrm{T}$ & $\mathrm{y}$ & $\mathrm{po}$ & $\mathrm{t}$ & $\mathrm{T}$ \\
\hline
\end{tabular}

Abnormal Return Differences Before And After Amnesty Tax Policy 2016 - 2017 Period II And III (Event Study at Company divided in LQ45 Index)

Hadi Cahyono, Hafiz fitradiansyah 
Volume 1 Number 12017

This work is licensed under a Creative Commons Attribution-

ShareAlike 4.0 International License.

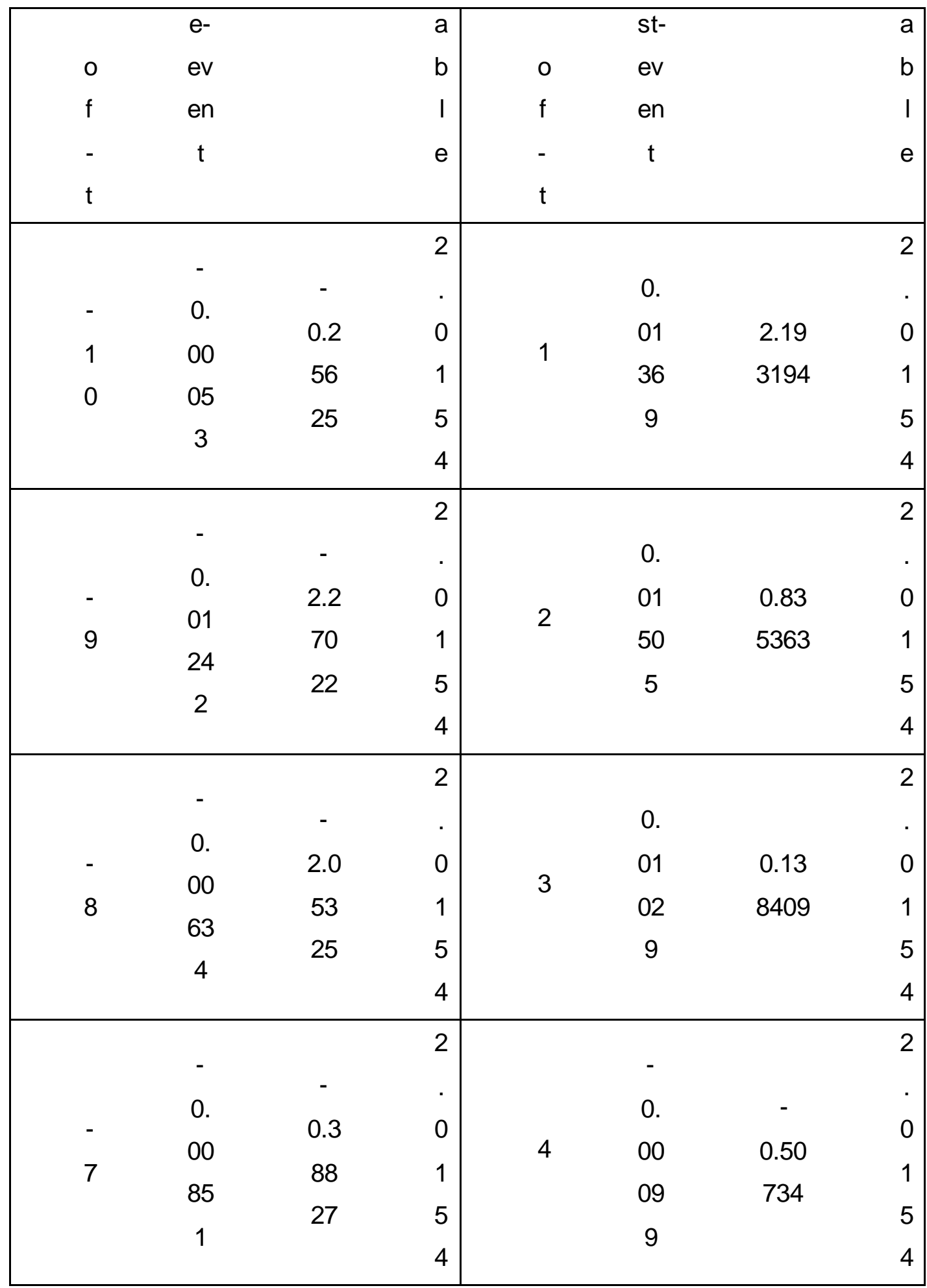

Abnormal Return Differences Before And After Amnesty Tax Policy 2016 - 2017 Period II And III (Event Study at Company divided in LQ45 Index)

Hadi Cahyono, Hafiz fitradiansyah 
Volume 1 Number 12017

This work is licensed under a Creative Commons Attribution-

ShareAlike 4.0 International License.

\begin{tabular}{|c|c|c|c|c|c|c|c|}
\hline & & & 2 & & & & 2 \\
\hline & 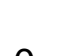 & - & . & & 0. & & . \\
\hline- & 0. & 1.6 & 0 & & 00 & 1.23 & 0 \\
\hline 6 & 01 & 61 & 1 & $\checkmark$ & 55 & 705 & 1 \\
\hline & 40 & 94 & 5 & & 3 & & 5 \\
\hline & & & 4 & & & & 4 \\
\hline & & & 2 & & & & 2 \\
\hline & 0 & - & . & & 0. & & . \\
\hline- & 0. & 1.1 & 0 & & 00 & 0.20 & 0 \\
\hline 5 & 00 & 72 & 1 & 0 & 57 & 2704 & 1 \\
\hline & 0 & 46 & 5 & & 4 & & 5 \\
\hline & & & 4 & & & & 4 \\
\hline & & & 2 & & & & 2 \\
\hline & 0. & 7.8 & . & & 0. & & . \\
\hline- & 02 & 69 & 0 & 7 & 00 & 006 & 0 \\
\hline 4 & 18 & 92 & 1 & 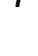 & 31 & 0.00 & 1 \\
\hline & 5 & 6 & 5 & & 2 & & 5 \\
\hline & & & 4 & & & & 4 \\
\hline & & & 2 & & & & 2 \\
\hline & 0. & 2.8 & . & & 0. & & . \\
\hline- & 03 & 21 & 0 & 8 & 00 & 0.62 & 0 \\
\hline 3 & 43 & 12 & 1 & & 15 & 1284 & 1 \\
\hline & 8 & 1 & 5 & & 8 & & 5 \\
\hline & & & 4 & & & & 4 \\
\hline & 0. & 0.7 & 2 & & - & & 2 \\
\hline- & קח & o. & $\cdot$ & & 0. & - & $\cdot$ \\
\hline 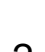 & (2) & 12 & 0 & 9 & 00 & 2.22 & 0 \\
\hline 2 & $\begin{array}{c}34 \\
1\end{array}$ & 09 & 1 & & 17 & 049 & 1 \\
\hline & 1 & 1 & 5 & & 7 & & 5 \\
\hline
\end{tabular}

Abnormal Return Differences Before And After Amnesty Tax Policy 2016 - 2017 Period II And III (Event Study at Company divided in LQ45 Index)

Hadi Cahyono, Hafiz fitradiansyah 


\begin{tabular}{|c|c|c|c|c|c|c|c|}
\hline & & & 4 & & & & 4 \\
\hline & & & 2 & & & & 2 \\
\hline & 0 & - & & & - & & \\
\hline- & 0. & 19 & 0 & 1 & 0. & - & 0 \\
\hline 1 & 00 & 82 & 1 & & 00 & 0.61 & 0 \\
\hline 1 & 21 & 83 & 1 & 0 & 67 & 719 & 1 \\
\hline & 3 & 11 & 5 & & 2 & & 5 \\
\hline
\end{tabular}

Table 3.6 above shows that on the event period III, there is significant abnormal return that happen for some days both pre- and post- event. In preevent, the significant t-count of abnormal return can be found on t-9 is as much as -2.27022 , $\mathrm{t}-8$ is -2.05325 , $\mathrm{t}-4$ is 7.869926 and $\mathrm{t}-3$ is 2.821121 . While for postevent, the significant t-count of abnormal return can be found on $t+1$ is as much as 2.193194, and $t+9$ is -2.22049 . For $t$-count of the entire AAR shows that there is significant t-count or be outside of the rejection area $\mathrm{H}_{0}$, so it can be concluded that there is significant abnormal return on $t-9, t-8, t-4, t-3, t+1$ and $t+9$ of events.

\section{DISCUSSION}

The event of tax amnesty also can be used as the reflection of a torrential capital inflow to become positive sentiment although it is continuously decreasing in each period. Investors can utilize the momentum where the market goes up and down, as long as they know how to behave on the market condition, and how to use the obtained information in associated with the events happened. It supports the theory of market efficiency, where the determiner of market response on an event is how deep the information absorption level which can be utilized to get abnormal return, hence it will be formed a new balancing price if the market can give response quickly and accurately (Jogiyanto, 2016).

Abnormal Return Differences Before And After Amnesty Tax Policy 2016 - 2017 Period II And III (Event Study at Company divided in LQ45 Index)

Hadi Cahyono, Hafiz fitradiansyah 
Significancy testing through paired-samplet test method shows that there are cumulative average differences of abnormal return on pre- and post-event of tax amnesty period III. However, it is different with the testing on the tax amnesty period II where there is no any cumulative average difference of abnormal return. If daily breakdown is done, abnormal return actually has happened in some days around the pre-event of tax amnesty period II and III, although the abnormal return on the event $\mathrm{t}-2$ is appropriate with the third hypothesis testing result. Yet, it still can't support the first hypothesis testing result because of the less testing requisite statistically in order to be said that there is abnormal return on the event of tax amnesty period II. Result of the second hypothesis according to the research done by Asmorojatun et al. (2016), Wulandari et al. (2016) and Rahayu (2016) where it exists the difference on abnormal return pre- and post-event of tax amnesty period I. Furthermore, on the the forth hypothesis analysis result shows the suitability amongs the research results done by Anwar and Sandimitra (2014), Nisak (2015) and Musyarrofah (2015) that on $\mathrm{t}-4, \mathrm{t}-3$ and $\mathrm{t}+1$ are happened significant abnormal return.

Investor as one of stakeholders who run the capital market has a unique characteristic as individual has. Some investor has a characteristic to be calmer and has a tendency to wait and see in facing an event. Some other investor has a tendency to behave opportunist in facing and posturing an event under the high gain high risk principle that implemented in the form of taking profit or minimalizing the loss by following the stock flow where its movement is fluctuative enough. One of the phenomenons can be found during tax amnesty program being implemented is the raising value of some stocks, especially Bakrie Group's, such as: BUMI, ELTY dan ENRG. It is likely that the raising value of those stocks is because of the investors want to taking profit in gross. For example, it can be seen on BUMl's stock, which stands in the price level of 
50 rupiahs, increases into the price level 5000 rupiahs or 10 times over from the early price in the second period. From the example, it can be estimated the profit obtained by the investors with big capital if they buy BUMI stock on buy position in the beginning period II.

The main thing needed to be paid attention is correspond to Nawacita Program by President of Joko Widodo related to infrastructure development as the booster of state's economy wheel, the implementation of tax amnesty policy brings positive impact, that is repatriachy and compensation fund flow as much as 282 quintillion rupiahs which come from taxpayers go into state's cash and then it will be used by the government to implement Nawacita program according to the table 2.1 about the requirement list of government development period 2015-2019. By the more incessant infrastructure development in many sectors, indirectly it will increase the investor's confidence and optimism to invest in Indonesia, in such a way it raises the assumption that Indonesia economy will move to the more positive way and will grow significantly. Some BUMN emitents that get trusty to run strategical project from the government, such as: PT. PP (Persero) Tbk., PT. Waskita Karya (Persero) Tbk., PT. Adhi Karya (Persero) Tbk., and PT. Wijaya Karya (Persero) Tbk. also get positive sentiment in the form of optimism from the investors to the improvement of company's performance, so their price level and extrinsic value are raising both in short-term and long-term.

Various reactions are shown by the investor in posturing tax amnesty implementation period I, II, and III. On the first period of tax amnesty, investors tend to wait and see before the program being started. Society anthusiasm to participate in tax amnesty is more than the expectation, so that market gives positive response and move the market into the higher new price level. In the last first period, the market agent appreciates the program achievement hence it raises positive sentiment on tax amnesty period II as expected to get both fund 
This work is licensed under a Creative Commons Attribution-

ShareAlike 4.0 International License.

declaration and compensation fund more than period I. However, the implementation of tax amnesty in period II, it is obtained the result that the achievement of fund declaration and fund compensation is not much as in the first period hence market reacts fluctuatively and the investors do taking profit action, and as the consequences is some stocks registered in IHSG and LQ45 get down and boost the IHSG and LQ45 to go down into the price level of early period I of tax amnesty. In period III, although the achievement of tax amnesty program is not as high as period I and II, but the investor has known how the movement pattern of capital market in the early period. So the investor is just waiting for the momentum on the point where they should do taking profit or cut loss to get maximum profit and also to minimize the loss or the beared risk. From those three periods, it can be assumed that abnormal return is very likely often happened in the third period, because the investor has understood how the market respond to the performance and the achievement of tax amnesty program and the existence of investor tendency to boost the stock price and the indexes to the higher level after the incisive declining in the second period.

If it is seen from macro-economy point of view, positive sentiment in the form of the raise of foreign investor's trust to the economy growth in Indonesia when tax amnesty being implemented, make Rupiah rate of exchange ever reach the level of $\mathrm{Rp} .12 .925$ on September $28^{\text {th }}, 2016$ for exactly or 2 days before tax amnesty period II being implemented (kontan.co.id, 2016). It is in tune with what have been said by financial ministry, Sri Mulyani (27/9) that the reinforcement of rupiah exchange to dollar AS is supported by foreign fund flow into the country and tax amnesty program and also other factors that is the certainty of FED interest rate which is raise on that period, hence it gives an opportunity for the investors to give their trust to Indonesia economy although the reinforcement also has impact on the General Revenue and Expenditure Budget (APBN) of the country which come from the export sector and natural

Abnormal Return Differences Before And After Amnesty Tax Policy 2016 - 2017 Period II And III (Event Study at Company divided in LQ45 Index)

Hadi Cahyono, Hafiz fitradiansyah 
resources (cnnindonesia.com, 2016). That fund flow will be accommodated by the bank appointed by the government previously and then will be channeled in the form of credit distributing to support infrastructure development which has been defined in Nawacita program of president of Joko Widodo. The biggest challenge faced by tax amnesty is how the way to influence the tax-dodger and Indonesian who saves their fund outside the country to give their contribution by declaring their own asset and also compensating their arrears. Besides that, Singapore as one of fund "parking lot" countries for the large-scale customers from Indonesia gets impact by the threatening of assets saved as the result of tax amnesty implementation. So that, Singapore applies some ways for Indonesian people who have assets to not joint in tax amnesty program, as mentioned by Hotman Paris (27/9) that are: by giving incentive in the form of higher interests offering, determining the deposits minimum limit, and also a persuassion as if saving their money in Indonesia, they will get a problem (cnnindonesia.com, 2016).

Micro-economically, tax amnesty also gets protest from inside in the form of demonstration by laborers to revoke Tax Amnesty Law (kompas.com, 2016). They state that tax amnesty only causes the corporation or company with tax problems to enjoy a benefit; hence the policy is looked as hurting the justice for the labor. They urge the government to set out the taxpayer intensification and extensification and also a reformation in tax sector as the solution. However, it is clarified by the secretary of cabinet, Pramono Anung that the law of tax amnesty is not related to labor destiny and thinks that the purpose of tax amnesty program is not informed well yet. So, the intense education about Tax amesty law needs to be given to the society. Although there is an oppugnancy, but tax amnesty program is still running well and give impact on the improvement of state's economy. When repatriachy fund and compensation fund of tax amnesty is used to build infrastructure of economy supporter, hence

Abnormal Return Differences Before And After Amnesty Tax Policy 2016 - 2017 Period II And III (Event Study at Company divided in LQ45 Index)

Hadi Cahyono, Hafiz fitradiansyah 
This work is licensed under a Creative Commons Attribution-

ShareAlike 4.0 International License.

the expense both financial and time consumed during production and distribution process can be pressed optimally. Beside that, the many more projects are progressed the more open new vacancies hence the manpower absorption can be maximized. The next impact is the improvement of living standard of manpower and society around the project area because of many transactions happened to fulfill living needs, and because of the income improvement, it is automatically affecting society's purchasing power hence it can move economy wheel start from the medium-small business (UKM) level. Beside, this income improvement statistically is also affecting Gross Domestic Product (GDP) nationally and finally it can become the reflection of Indonesia economy growth level.

Post-event of tax amnesty, beside Indonesia become the success country in the program implementation, Indonesia also gets positive note from some institutions in the world related to investation rating, such as by Standard \& Poor's (S\&P) leveler that increases Indonesia's level to Investment Grade with the early level BB+ become BBB-. Moody's Investor Service and Fitch Ratings is also give positive view related to Indonesia's credit rating. Distributed by Bloomberg in marketbisnis.com that the increasing rating is not free from tax amnesty success in getting state income more than US\$11 billion and helps to lessening the budged for infrastructure project. It is expected that after that rating, positive sentiment will raise related to short-term and long-term investment prospect in Indonesia.

In the end, tax amnesty is succeeded to give significant impact, especially on Indonesia capital market activity. So next, it is expected that not only financial sector which get positive impact but another sectors can also get benefit of capital inflow, hence they can contribute to Indonesia economy improvement entirely. Tax amnesty has become a reformation turning point of taxation system bureaucracy in Indonesia where it is expected as the trigger of

Abnormal Return Differences Before And After Amnesty Tax Policy 2016 - 2017 Period II And III (Event Study at Company divided in LQ45 Index)

Hadi Cahyono, Hafiz fitradiansyah 
taxpayer to be more discipline in paying the tax and not ashamed to report their assets so it raises a transparency system in taxation sector because the government has warned the taxpayer who doesn't obey taxation regulation and doesn't follow tax amnesty program have entered in tax official police monitoring.

The reviews above can strength the assumption that although the indexes or market has a very fluctuative condition, it doesn't mean the emitents, indexes or market can give a significant abnormal return. In associated with the assumption, it can be concluded that an event cannot be said to be existed and make abnormal return although it is happened a fluctuative pattern graphically. Yet, it is needed a deeper testing statistically in order to be able to prove that the event makes significant abnormal return both cumulatively and daily in duration defined in a research.

\section{CONCLUSION}

Based on the analysis and discussion about a significant difference abnormal return on LQ45 indexes pre- and post-event of tax amnesty policy 2016-2017 period II and III applied on the company registered in LQ45 indexes in previous chapter, hence it can be concluded as follow:

1. Testing result of the first hypothesis shows that $\mathrm{H}_{0}$ is fail to be rejected. It means that there is no any difference of abnormal return on the company registered in LQ45 indexes. While, the value of cumulative abnormal return at pre-event shows higher value than at post-event. It can be assumed that the market reacts positively by making preparation to taking profit after the event happened.

2. Testing result of the second hypothesis shows that $\mathrm{H}_{0}$ is rejected. It means that there is abnormal return difference on the company registered in LQ45 indexes. While, the value of cumulative abnormal 
Volume 1 Number 12017

This work is licensed under a Creative Commons Attribution-

ShareAlike 4.0 International License.

return on LQ45 indexes at pre-event is lower than at post-event. It can be assumed that the market reacts on the achievement of tax amnesty program period II and also there is a tendency to wait and see on tax amnesty period III.

3. Testing result of the third hypothesis shows that $\mathrm{H}_{0}$ is rejected because there is a day where a significant abnormal return is happened on LQ45 indexes. For exactly, It is the first day of pre-event. It can be assumed that the investor make a sell decision to prepare taking profit as their response on the starting of tax amnesty program period II.

4. Testing result of the fourth hypothesis shows that $\mathrm{H}_{0}$ is rejected because there is a day where a significant abnormal return is happened on LQ45 indexes, for exactly, on the $3^{\text {rd }}, 4^{\text {th }}, 8^{\text {th }}$, and $9^{\text {th }}$ days of pre-event and also on the $1^{\text {st }}$ and $9^{\text {th }}$ days of post-event. It can be assumed that the investor has predicted the market movement based on the two tax amnesty period before by measuring fluctuative level based on the market response on the achievement of tax amnesty period II 


\section{REFERENCES}

Adi, T. (2016, Oktober 1). Investasi Sepekan: Hore, rupiah Rp 12.000. Diambil kembali dari Kontan: http://investasi.kontan.co.id/news/investasisepekan-hore-rupiah-rp-12000

Andriani, R. S. (2017, Maret 29). Perbaharui Rekor Penutupan Tertinggi, IHSG Dekati Level 5.600. Diambil kembali dari market.bisnis.com: market.bisnis.com/read/20170329/7/641032/perbaharui-rekorpenutupan-tertinggi-ihsg-dekati-level-5.600

Anwar, F., \& Sandimitra, N. (2014). Analisis Perbandingan Abnormal Return, Trading Volume Activity dan Bid-ask Spread Sebelum dan Sesudah Stock Split. Jurnal IImu Manajemen Volume 2 Nomor 3 Juli 2014, 880 893.

Asmorojati, W., Diana, N., \& Afifudin. (2016). Reaksi Investor Terhadap Pengumuman Kebijakan Tax Amnesty Pada Tanggal 1 Juli 2016 (Event Study pada Perusahaan LQ45 yang Terdaftar di BEI). e_Jurnal IImiah Riset Akuntansi, 27-41.

BEI, I. (2010). Saham. Diambil kembali dari idx.co.id: http://www.idx.co.id/idid/beranda/produkdanlayanan/saham.aspx

Belarminus, R. (2016, September 29). Alasan Buruh Minta Pemerintah Cabut UU "Tax Amnesty". Diambil kembali dari Kompas.com: http://megapolitan.kompas.com/read/2016/09/29/12580601/alasan.buruh .minta.pemerintah.cabut.uu.tax.amnesty.

Development, U. N. (2016). Global Investment Prospects Assesment 20162018. Global Investment Trends Monitor, 10.

Direktorat Jenderal Pajak Kementrian Keuangan. (2016, Maret 23). Refleksi Tingkat Kepatuhan Wajib Pajak. Diambil kembali dari pajak.go.id: 
Volume 1 Number 12017

This work is licensed under a Creative Commons Attribution-

ShareAlike 4.0 International License.

http://www.pajak.go.id/content/article/refleksi-tingkat-kepatuhan-wajibpajak

Direktorat Keuangan ITB. (2016, Agustus). Diambil kembali dari ditkeu.itb.ac.id: www.ditkeu.itb.ac.id/wp/wp-content/uploads/2016/08/1 .-PresentasiPengantar-Amnesti-Pajak.pptx

Dolorosa, G. N. (2017, Maret 16). Rekor Baru, Kapitalisasi Pasar Saham Tembus Rp. 6.012 Triliun. Diambil kembali dari market.bisnis.com: http://market.bisnis.com/read/20170316/7/637713/rekor-barukapitalisasi-pasar-saham-tembus-rp6.012-triliun

Fakultas Ekonomi Bisnis Universitas Gajah Mada Yogyakarta. (2016, Mei 10). Repatriasi Dana dan Konsekuensinya. Diambil kembali dari Macroeconomic Dashboard Fakultas Ekonomika dan Bisnis UGM: http://macroeconomicdashboard.feb.ugm.ac.id/repatriasi-dana-dankonsekuensinya/

Fauzie, Y. Y. (2016, September 28). Sri Mulyani: Penguatan Rupiah Karena Amnesti Pajak. Diambil kembali dari CNN Indonesia: https://www.cnnindonesia.com/ekonomi/20160928002931-78-161644/srimulyani-penguatan-rupiah-karena-amnesti-pajak/

Femianita, R. T., \& Asandimitra, N. (2014). Reaksi Pasar Sebelum dan Sesudah Kenaikan Harga BBM Pada Perusahaan yang Listing di Bursa Efek Indonesia (BEI). Jurnal IImu Manajemen Volume 2 Nomor 3 Juli 2014, 1069-1079.

Heze, E. (2017, Maret). Kriteria dan Syarat Saham Masuk LQ45. Diambil kembali dari sahamgain.com: http://www.sahamgain.com/2017/03/kriteria-dan-syarat-saham-masuklq45.html 
This work is licensed under a Creative Commons Attribution-

ShareAlike 4.0 International License.

Jogiyanto, H. (2013). Teori Portofolio dan Analisis Investasi. Yogyakarta: BPFEYogyakarta.

Jupriyanto, M. (2016, September). Sejarah Tax Amnesty di Indonesia . Diambil kembali dari Lembagapajak.com:

http://www.lembagapajak.com/2016/09/sejarah-tax-amnesty-diindonesia.html

Kementrian Keuangan Direktorat Jenderal Pajak. (2016). amnesti pajak. Diambil kembali dari http://www.pajak.go.id: http://www.pajak.go.id/sites/default/files/Handout-Materi-AmnestiPajak.pdf

Kuwado, F. J. (2016, September 30). Pramono Anung: UU Amnesti Pajak Tak Ada Kaitannya dengan Upah Buruh. Diambil kembali dari Kompas.com: http://nasional.kompas.com/read/2016/09/30/08281981/pramono.anung. uu.amnesti.pajak.tak.ada.kaitannya.dengan.upah.buruh

MacKinley, A. C. (1997). Event Studies in Economic and Finance. Journal of Economic Literature Vol. XXXV March 1997, 13 - 39.

May, E. (2016, September 15). Mengenal LQ45. Diambil kembali dari Detik Finance: https://finance.detik.com/bursa-valas/3298411/mengenal-lq-45 Musyarrofah, A. (2015). Reaksi Pasar Modal Indonesia Sebelum dan Sesudah Reshuffle Kabinet 12 Agustus 2015 (Event Study pada Saham Anggota LQ45 Tahun 2015).

Ningsih, E. R., \& Cahyaningdyah, D. (2014). Reaksi Pasar Modal Indonesia Terhadap Pengumuman Kenaikan Harga BBM 22 Juni 2013. Management Analysis Journal Universitas Negeri Semarang, 1-5.

Nisak, F. U. (2015). Analisis Reaksi Pasar Modal terhadap Pengumuman Right Issue pada Perusahaan Go Public di Bursa Efek Indonesia Tahun 2009 - 
2013. Yogyakarta: Universitas Negeri Yogyakarta.

Nugroho, A. C. (2017, Mei 19). Nilai Tukar 19 Mei: Indonesia Dapat Investment Grade, Rupiah Berbalik Menguat. Diambil kembali dari Bisnis.com: http://market.bisnis.com/read/20170519/93/655350/nilai-tukar-19-meiindonesia-dapat-investment-grade-rupiah-berbalik-menguat

Olavia, L. (2017, Februari 1). Berkat Tax Amnesty, Jumlah Investor Domestik Mendominasi Pasar Modal. Diambil kembali dari beritasatu.com: http://www.beritasatu.com/pasar-modal/412286-berkat-tax-amnestyjumlah-investor-domestik-mendominasi-pasar-modal.html

Praditya, I. I. (2017, April 1). Resmi Berakhir di 31 Maret, Ini Hasil Tax Amnesty Diambil kembali dari bisnis.liputan6.com: http://bisnis.liputan6.com/read/2906371/resmi-berakhir-di-31-maret-inihasil-tax-amnesty

Primadhita, S. (2016, September 27). Hotman Paris Bongkar Modus Bank Singapura Jegal Tax Amnesty. Diambil kembali dari CNN Indonesia: https://www.cnnindonesia.com/ekonomi/20160927142725-78-

161467/hotman-paris-bongkar-modus-bank-singapura-jegal-taxamnesty/

PT. Kustodian Sentral Efek Indonesia. (2016, Desember 30). Kinerja KSEI Tahun 2016: Raih Penghargaan sebagai Kustodian Sentral di Asia Tenggara. Jakarta.

Rahayu, D. (2016). Analisis Reaksi Pasar Modal Terhadap Kebijakan Amnesti Pajak (Studi Kasus pada Saham-saham Syariah yang Masuk Daftar JII Periode Juni-November 2016). UIN Sunan Kalijaga Yogyakarta.

Rudiyanto. (2017, Januari 2). Evaluasi Kinerja 2016 dan Prediksi Kinerja Investasi 2017. Diambil kembali dari http://blog.kontan.co.id/: 
http://rudiyanto.blog.kontan.co.id/2017/01/02/evaluasi-kinerja-2016-danprediksi-kinerja-investasi-2017/

Senastri, C. P. (2015). Perbedaan Abnormal Return dan Trading Volume ActivitySebelum dan Sesudah Pengumuman PP Nomor 1 Tahun 2014 (Studi pada Saham Sektor Pertambangan yang listing di ISSI). Surabaya: Universitas Airlangga.

Setiawan, H. (2008). Pengaruh Pengumuman Akusisi Terhadap Return Pemegang Saham Perusahaan Pengakuisisi. Jakarta: Universitas Indonesia.

Setyawasih, R. (2007). Studi Tentang Peristiwa (Event Study): Suatu Panduan Riset Manajemen Keuangan di Pasar Modal. Jurnal Optimal Vol. 1 No. 1, 52 - 58.

Staff, I. (2005, Juli 30). Beta. Diambil kembali dari Investopedia.com: http://www.investopedia.com/walkthrough/fund-

guide/introduction/1/beta.aspx

Supragita, I. (2013). Reaksi Pasar Modal atas Peristiwa Pengumuman Pengunduran Diri Menteri Keuangan dari Kabninet Indonesia Bersatu. Bengkulu: Universitas Bengkulu.

UU No. 11 Tahun 2016 tentang Pengampunan Pajak. (2016).

Wardhani, L. S. (2013). Reaksi Pasar Modal Indonesia terhadap Peristiwa Pemilihan Gubernur DKI Jakarta Putaran II 2012 (Event Study pada Saham Anggota Indeks Kompas 100). Malang: Universitas Brawijaya.

Wulandari, G. A., Wahyuni, M. A., \& Sujana, E. (2017). Reaksi Investor dalam Pasar Modal Terhadap Undang-Undang Tax Amnesty (Event Study pada Perusahaan yang Terdaftar dalam LQ45). e-journal S1 Ak Universitas Pendidikan Ganesha Volume 7 Nomor 1. 
International Journal of Entrepreneurship and Business Development

Volume 1 Number 12017

This work is licensed under a Creative Commons Attribution-

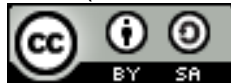

ShareAlike 4.0 International License.

Yuniarthi, N. N., \& Sujana, I. K. (2016). Reaksi Pasar Modal terhadap Pencalonan Jokowi menjadi Presiden Republik Indonesia. E-Jurnal Akuntansi Universitas Udayana Vol 16.2 Agustus 2016, 951 - 977.

Zaqi, M. (2006). Reaksi Pasar Modal Indonesia Terhadap Peristiwa - Peristiwa Ekonomi dan Peristiva - Peristiwa Sosial-Politik Dalam Negeri (Studi pada Saham LQ45 di BEJ Periode 1999-2003). Semarang: Universitas Diponegoro.. 